\title{
Past the Post?: Screening Progress and Reappearing Fascism
}

\author{
David A. Gerstner \\ City University of New York, College of Staten Island, USA, \\ david.gerstner@csi.cuny.edu, cuny.academia.edu/DavidGerstner
}

\begin{abstract}
The 2016 presidential election triggers many unanticipated responses. Emotions run high. Political activists discover newfound energy. One's place in the world becomes unfixed, troubled, and unsettled. Philosophers and artists, stunned, rethink the terms for their critical positions and the formal aesthetics that shape their work. The moment is thus rife with anxiety in search of a response. As a film scholar, I find myself driven to script a response. Ironically, as I write I feel paused in time and space. My unfixedness, in the shadow of the election, has put in motion what can best be described as quivering stasis. From my troubled place, an intellectual processing unfolded. I conjured ideas and images that invariably failed to yield a satisfactory response to what had come to pass. What had I seen? Felt? My psychical and physical response to current events might be likened to what Adorno refers to as "the capacity to shudder, as if goose bumps were the first aesthetic image" $(1997,437)$.

It's not a pretty picture. But we've known this all along.
\end{abstract}

Keywords: Screen Culture, Donald Trump, Fascism, Film Studies, Critical Theory

I.

It was commonplace during the presidential election to compare Donald Trump's candidacy as a moment mirroring a return to historical fascism. New Hitler biographies were trotted out and reviewed in prestigious newspapers, where uncanny resemblances were made between the figure of fascism-past and fascism-present. Elsewhere, "Germany 1933" stood in as the historical benchmark, a tale of caution. By invoking "Germany 1933" we were encouraged to recall how easily large national populations blindly rode the wave of populism directly into the arms of totalitarianism. Such comparisons are not unwarranted, given "alt-right's" "Heil Victory" salutes at their post-election conference in Washington, DC. Breitbart News, "reality TV," and "fake news" resounded as if to mimic Gœbbel's news-making machinery.

Nevertheless, the weight given to "fascism" during the 2016 election in the United States and its re-authorisation for sustained use in popular discourse remained remarkable. Not too long ago, those who publicly uttered "fascism" with intent to disparage political movements and high-profile figures were called into question. In charging others with exhibiting behaviour or articulating ideas that aped Nazi-like tactics, "neutral" pundits and politicians lamented the overuse of the term. By pointing to "fascism" at every ideological turn, they argued, the horror of historical fascism was cheapened. "As with 'Nazi' or 'Hitler," Michael Kinsley (2017) writes in The Washington Post, "it is often said that in any discussion, the first person reduced to using such a word has lost the argument." It is, Kinsley reminds us, "an all-purpose epithet".

Indeed, as early as 1944, George Orwell in his essay, "What is Fascism?" illustrated the way redundant and random claims to fascism quickly became meaningless. For Orwell, "fascism" was le mot du jour, applied to just about anything and 
anyone, from "farmers" to "fox-hunting." For twenty-first-century American media pundits, Orwell is the go-to thinker for shoring up their criticism when they perceive fascism reduced to empty rhetoric and political gain. During the run-up to the 2016 election campaign, the term, and the debate, returned. Geoffrey Wheatcroft, in The New York Times (2015), found it necessary to remind readers of Orwell's warning: "we should take care not to wear the word 'fascism' out with overuse, lest we fail to recognize the real thing, if it does reappear." But if we are to pay heed to Wheatcroft's argument, how do we know the "real thing," when and "if it does reappear" [my emphasis]? How will we know when it is appropriate to reintroduce "fascism" into political and everyday discourse? What if Wheatcroft's cautionary "if" neglects fascism's complex schedule for arrival and departure? Indeed, is there such a thing as "historical" fascism that one may decidedly mark with a beginning and an end?

Because this is no easy set of questions to answer, more pressing questions might be posed: If fascism has returned in the body of Donald Trump, when did fascism officially "end"? Is Trump the worrisome "if" about which Wheatcroft warned? If we abide Kinsley and Wheatcroft's historical markings of fascism, it would seem that fascism took a break at the end of World War Two. In doing so, postwar 1945 yielded a "post-fascist" period. But did fascism just arrive, once again, with Trump in the seat of the presidency? Or have we seen it all before in more complex divinations? To consider how we might "see" fascism "if" and when it takes the stage (or if one prefers, how we see it here and now), it is helpful to return to the writings of those who lived through the severe thrust of historical fascism and its mediation in the twentieth century. It is useful, therefore, to pause and return to the work of intellectuals and artists whose reflections on fascism emerged at a moment when a particular stream of ideology and practice came to power carrying the very name, "Fascism." By making a return (as is often done) to those who lived through the terror of the period, and to those who then reckoned with fascism's declared end, we discover an immediacy of a moment in their writing. We encounter writing, in other words, that queries the time and place of fascism, and whether or not the final curtain has, "if" ever, fallen on fascism.

At the risk of repeating well-worn theoretical enterprises, I nonetheless find myself drawn to the Frankfurt School's reflections on fascism and culture, particularly their ruminations on whether or not the "post" prefix may be assigned to fascism. It seems to me that their work is worth revisiting (repeating and revising) since new generations are now actively engaging in discussions about the return of "fascism" in our day and age. A revisit to Walter Benjamin's essays, "The Work of Art in the Age of Technical Reproducibility" (1986, specifically 217-52) and "Theses on the Philosophy of History" (1986, 253-64), as well as Max Horkheimer's and Theodor Adorno's essay "The Culture Industry: Enlightenment as Mass Deception" (2002, 94-136) is once again timely. On the one hand, Frankfurt School writings provide clear fascist signposts, especially those manufactured through the media industries (movies, radio, advertising); on the other hand, Frankfurt School critical theory requires that we invest in fascism something more than its material realisation. These writings also reappear, over time, strengthened during opportune moments when ideological awakenings occur in the midst of political unrest and strident authoritarianism. Hence, under different historical circumstances during the 1960s, French thinkers and artists returned to the tricky mechanisms of fascism to untangle the difficult relationship between abstract thought and material practice. By posing Frankfurt School concepts side-by-side with French "poststructuralist" thought, we can at once take account of fascism as it is witnessed in the thick of world war, and as it is reconsidered in the 
late 1960s and early 1970s far from the war zone. My sense is that, following the election in the United States (if not recent elections around the world), the Frankfurt School and the French poststructuralists who followed in their wake are perfectly placed for their encore in 2017.

II.

So many questions, so few answers.

Samuel Weber (1996)

What is striking about these writers who form the Frankfurt School (and there are, of course, others), is that they challenge what we so readily accept as post-fascism. The logic is simple: by marking fascism as "post", we create a narrative to protect ourselves from a fascism-yet-to-come. As the Frankfurt School saw it, however, there is more to fascism than meets the eye and ear. The German philosophers made clear in no uncertain terms that there is no "if" and when regarding fascism's reappearance. Fascism is always already present. It is an impulse, an ideological and psychological drive; it is not easily cordoned off by past, present, or future. While fascism reaches its modernist heights through twentieth-century technical reproducibility so as to press forward models of capitalist efficiency and functionalism, fascism is not dateable as such. This is not to say that authoritarian regimes who identified as "Fascists" cannot be historically documented. Historical Fascists are recognised - made visible - for their actions against humanity. "Fascists" exist. Indeed, we are witness to their historical atrocities as recorded in history books, films, photographs, diaries, and so on. As such, it is worth considering a distinction between "Fascist" and "fascism."

The three essays taken up here are prescient not only because they offer insight from within Fascism, and point clearly to its visible signposts; they put on notice those who oversimplify fascism as a singular historical event, marked by a beginning, a middle, and an end. To hastily conflate the historical Fascist period with fascism's ideological currents is to confuse a significant theoretical and affective point.

Setting aside the view that fascism may be discretely framed in time and place, the Frankfurt School (and their outlier, Benjamin) offered a less-than cheerful version of "post"-fascism. In short, they leave us with "bad news" and, arguably, somewhat "better news." The "bad news" is that we will never see fascism "appear" as such. Why is this "bad news"? Because it is impossible to recognise fascism's reappearance, since it is always already on the scene. Each and every day media-culture apparatuses inculcate ideology, disciplining mind and body. Most chillingly, as Horkheimer and Adorno argue in "The Culture Industry," mediated inculcation does not instil Pavlovian response; instead, it deceives the masses that their individuality is unique, and that their "opinions" matter. The culture industry generates a ruse of difference. Bifurcating "left/right," or "liberal/conservative," the media industry narrativises politics through the lens of "good guy" and "bad guy." To "choose" a side, in other words, is to make no choice at all. Mediated battles between Republican and Democrat, Fascist and Social Democrat, give the appearance of ideological difference when they are, in effect, "perpetual sameness" $(2002,157)$. Why? Because the perception of political difference as presented through the media is part and parcel of consumer culture. Entertainment masquerades as the political and, in turn, the political - in assuring media coverage - must masquerade as entertainment. One coin, two sides, with very little distinction when tossed. 
One need only attend a White House Correspondence Dinner (where opposing forces break bread with folks in the media industry) to witness the "bipartisan" celebration of difference-as-unity. The "culture industry" is the sweetened poison that masks the horrifying existence in which the modern world finds itself: "The ruthless unity in the culture industry is evidence of what will happen in politics. Marked differentiations such as those of $A$ and $B$ films, or of stories in magazines in different price ranges, depend not so much on subject matter as on classifying, organizing, and labeling consumers . . . Consumers appear as statistics on research organization charts, and are divided by income groups into red, green, and blue areas; the technique is that used for any type of propaganda" (97). It is not inaccurate to draw parallels between Horkheimer's and Adorno's remarks on the culture industry's colourcoding of consumers in 1944 ("into red, green and blue") and the 2016 news-media industry's categorisation of consumer-voters (into "red and blue states").

The "better news"? Because we cannot mark fascism's intrusion by strict calendar dates we may, nonetheless, disrupt its always-already-ness. For Benjamin (and later French poststructuralists), culture-industry's "propaganda" makes way for unexpected turns of events when authoritarianism strikes. Unlike his colleagues, Benjamin was less willing to disavow the effect of variation, the unexpected. Hence, while Horkeimer and Adorno contend that "Orson Welles is forgiven all his offences against the usages of the craft because, as calculated rudeness, they confirm the validity of the system all the more zealously" $(2002,102)$, Benjamin pushed a bit harder on the point. He, instead, turned a critical eye on the dynamic between the mass-produced movie image and the mass-produced audience. More collectively sensual than Adorno's individualised "shudder," Benjamin suggested that the cinematic experience and the "calculated rudeness" it allowed for, on and off screen, made way for en masse frisson.

If it is true that Welles's departures from the norm were mere deviations from aesthetic consistency in order to sell something "new" and different, Benjamin argued for a clear distinction between the films of, say, Charlie Chaplin and Leni Riefenstahl. Both drew the masses to the mass-produced work of art, but reached differing ends. It is important to recall, however, that Benjamin's vision for political possibility by the masses turns on the spectator's experience while assembled before a large movie screen. The giant screen is a crucial element for Benjamin's assertion, since he envisaged the politicisation of the masses precisely through the emergence of massmedia reproducibility. The point is significant for the political moment in which we find ourselves. How do we consider "mass politicisation" when the mediated landscape turns on very different screens? For "the work of art in the age of technical reproducibility" to mobilise political movement on the part of the masses it necessarily involves mass participation. The cinema in the early twentieth century functioned as a kinetic force in a social field. The dynamic launched within the time-and-space specificity of the cinema is precisely "aura" in the age of mechanical reproducibility. Writing under the intensifying cloud of fascism, Benjamin argued that the cinematic experience "shocked" the spectator; it prompted bodily movement and involvement within a movement. Today's screen redirects the spectator to the field of individualism. The jury is out on how we come to identify "aura" in the twenty-first century, or if the "new" technology unexpectedly returns us to nineteenth-century "contemplation" before the singular work of art.

A caveat must be inserted before one celebrates the "masses" and their political engagement. Benjamin underscored that the cinematic experience may generate politicised mass movements but the politicised masses may move, ideologically, in 
unanticipated ways. If the work-of-art's "aura" gives life to a politicised spectator - a commingling of aesthetic properties, content, and spectator - Benjamin's task was to understand how twentieth-century "technical reproducibility" revises the contours of the aura it generates. What is it that transforms within the shift from the individual encounter with a "unique" work of art (nineteenth-century painting) to that of a mass encounter with a mass-produced copy of the work of art (cinema)? During the nineteenth-century, on the one hand, the viewer's experience with a painting secured "aura" as a reaffirmation of bourgeois individualism: l'art pour l'art. The privileged one-on-one experience between viewer and work allowed for "contemplation", or a transcendence of self through art. Hence, the unique work brought into conveyance an ideal commingling of the "in-itself" and the "for-itself". Although the experience with the work of art radically changes with twentieth-century technology, the concept of aura does not evaporate. It is, quite simply, revised. Because aura alters through the technology of reproducibility, the aura it manufactures raises the stakes on the politicised individual. The work-of-art's auratic transformation from the nineteenth to the twentieth century thus metamorphosed the relationship to art. The reaffirmation of the individual was now the reaffirmation of the masses. Mass aura is fascism's seedbed. The political implications are significant. As such, every work of mechanically reproduced art lends itself to fascism's reappearance.

To different degrees, then, Horkheimer, Adorno, and Benjamin "recognised" fascism's appearance under the Nazis. They witnessed fascism's enhancement and expansion through technology. As the tools for modernity heightened fascism's dissemination, its ideology saturated media culture and politics, yielding material effects. On the one hand, fascism comes at us with violent mediated force (Nazis, Gœbbel's Propaganda of Ministry); on the other hand, fascism naturalises its own violence through the media channels that reproduce its ideology (Hollywood, the culture industry). Media is the critical tool that not only sustains fascist ideology in recognisable forms; it holds together "not aura as such but the aura of art as a work of representation, a work that would have its fixed place, that would take its place in and as a world-picture" (Weber 1996, 107). This is "progress." And this is fascism.

III.

"When I recognize all these merits of the Frankfurt School," Foucault reflects in $R e-$ marks on Marx, "I do so with the bad conscience of one who should have known them and studied them much earlier than was the case. Perhaps if I had read those works earlier, I would have saved useful time, surely . . . if I had encountered the Frankfurt School while young, I would have been seduced to the point of doing nothing else in life but the job of commenting on them" $(1991,119)$.

Foucault's remarks are stunningly worrisome for the cultural critic who grapples with the ever-returning concern that is fascism. Indeed, Foucault laments the late arrival of Frankfurt School thought in France, especially since the wartime "experiences" shared between the earlier generation of Germans and Foucault's own generation in France, if not "identical", were "in some ways very similar" (117). If the Frankfurt School tightened terms for theoretical rigour in advance of the unaware Foucault, they have indeed raised the ante for those of us who now must navigate rather pressing circumstances in the United States - circumstances that are certainly not "identical [but] in some ways very similar." To put ourselves in the game where the stakes are so high, a detour through French thought and its intersection with 
Frankfurt School philosophy (purportedly unread by the likes of Foucault) sheds useful light on the anxiety that surrounds fascism's imminent reappearance.

Since, as Foucault noted in 1978, the Frankfurt School "set problems that are still being worked on" (117), the "problem" for French thinkers came about with what soon became the left's metonymic calling card, "May 1968." Like Benjamin, et al. before them, Foucault's contemporaries remained unconvinced that "progress" was sailing along through political activism. They remained wary of doctrinaire claims made by both "left" and "right". Like their German postwar colleagues, French philosophers were concerned that fascistic impulses circulated on all political fronts. Specifically, they sensed fascism hovering over culture and politics in the name of progress (De Gaulle to the right, student activists to the left). The seduction of progress, the modernist ideal in the public imaginary, rests on a promise that modern life is a life that advances. It is the endless procession of the new. With progress, "it only gets better."

Indeed, "progress" was a key concern for Benjamin. "Progress", as he viewed it, requires equal critical attention as that of "fascism". It is not incorrect, in fact, to suggest that the terms are coupled for Benjamin. Together, they envelop ideological principles invested in final outcomes, strengthened by glittering waves of technology. Whether from the left or from the right, to champion "progress" as a cultural ideal is to pin false hopes on the political. If movement "forward" suggests ideological and/or material gains, then "progressive" politics is a ruse. To take a political side demonstrates consumer culture at its finest: "Social Democratic theory, and even more its practice," Benjamin contended, "have been formed by a conception of progress which did not adhere to reality but made dogmatic claims" $(1986,260)$. Like the poststructuralists who followed in his wake, Benjamin remained suspect of those who envisaged a utopic future that awaited them while they clung to a strictly defined movement. "The concept of the historical progress of mankind cannot be sundered from the concept of its progression through a homogenous, empty time. A critique of the concept of such a progression must be the basis of any criticism of the concept of progress itself" (261).

Progress is thus the crux of the "problem" set by the Frankfurt School, similarly understood by postwar French critics. For most, however, the challenge to the problems ("still being worked on") involved eking out modes - albeit limited - of resistance. If Adorno never came around to what were later marked by poststructuralists as "fissures" and "slippages" in culture-industry ideology (although it has been said that vaudeville and the circus were promising for Adorno), his friend Benjamin delighted in identifying - nay, participating in - a perversion of progress (consider his notes on "les pochettes-surprise" he discovered at a Parisian gay bathhouse [quoted in Gerstner 1999, 155]). Although mediauras (to borrow from Weber) permeated culture and art in such a way that it could tilt toward Fascist rule, he nonetheless believed that it is precisely through aura that the spectator is nevertheless politicised. The risk, of course, is that politicising the spectator can slip toward communism or fascism.

For post-May-1968 thinkers, locating breaks in fascist ideology was no less nuanced and complex. Since aura emanated from the material world, the French, like Benjamin (who embraced Parisian decadence), argued that resistance took place within it. Althusser, for example, wrangled with the distinction between Ideology and ideology, and their intermixing within state and cultural institutions. He provocatively drew on Freud and Lacan to grab onto historical practice as it materialised abstract ideology. Foucault's (1991) intricate, if not highly creative, archival tracing of discur- 
sive practice as repetition illustrated the epistemological formation of "Discourse" (madness, sexuality, meaning itself). If he claimed the "death of man" in Les Mots et les choses, he later introduced "points of resistance" and "reverse discourse" to signal an ounce of wiggle room within ideological containment.

Mirroring Horkheimer and Adorno's thinking in the "culture industry", the French Situationist Guy Debord restated, under different circumstances, the Frankfurt School's ideological premise. His 1967 book, The Society of the Spectacle, described, as Peter Wollen puts it, "how capitalist societies East and West (state and market) complemented the increasing fragmentation of everyday life, including labor, with a nightmarish false unity of the 'spectacle,' passively consumed by the alienated workers (a term understood in the broadest possible sense of non-capitalists and non-bureaucrats" (123). For Debord, then, students deceived themselves that liberation awaited them once they manned the barricades (they further deluded themselves that their political concerns were equal to those of the workers). As the Situationists saw it, student activists merely paraded their privileged bourgeois individualism and called it revolt. In their tract, "On the Poverty of Student Life", the Situationists spotlighted the students' sham-Bohemian protest as "phantastic compensation in the opium of cultural commodities." Again, the French response to fascist impulses inherent to progress may not have been "identical" to the Germans'; but they were indeed "very similar".

Importantly, and unlike the Frankfurt School, Debord and his fellow Situationists asserted their critical engagement as artists and theorists. And, as artists who drew upon Surrealist practices (a movement of whose members Benjamin was fond) and Georg Lukács's doctrinaire History and Class Consciousness, they foiled dogmatism from left and right through creative praxis. Resistance through aesthetic practice and critical theory came about precisely because of ideological containment. OULIPO, the French literary movement that coincided with poststructuralism and deconstruction, put their entire artistic stock in the possibilities which cultural constraint made available. What remained clear to the Situationists, as well as Benjamin, was that to engage art for political means through technological reproducibility was particularly complex, and particularly difficult because the aura it generated yielded unforeseen political responses by and consequences for the masses. With each gesture (brushstroke and, now, keystroke), the artist must anticipate the effect their gestures enable, since their work of art produces aura.

It is easy enough to trace "successes" in the joint project: art and politics. A direct line may be drawn from Frankfurt School theory and May-1968 praxis to late twentieth-century political activism in the United States (consider ACT-UP New York and Guerrilla Girls). In the twenty-first century, a new aesthetic-political project is underway through the likes of Occupy Wall Street (OWS) and Black Lives Matter. In the current age of technical reproducibility (digital media, Internet, social media), the link between art and the political appears, preliminarily, to invite protest as work of art. The critical difference between ACT UP and OWS is that we see aura yet again transformed by technology. With ACT UP, bodies came together through the distribution of material information (posters, fliers, and so on); with Black Lives Matters and OWS, bodies materialise from the virtual.

But the "set of problems" persist. Now, in the twenty-first century as in the twentieth, aura remains a double-edged sword. The risks are as high as ever. Does our return to a self-centred relationship with the screen-device return us to a revised version of l'art pour l'art? Does modern technology, ironically, return the work-of-art experience to one similar to nineteenth-century contemplation? Does the individual 
screen that absorbs and endlessly fascinates merely give the appearance of collective participation and political engagement? Has, returning our thoughts to Benjamin, "self-alienation [reached] such a degree that it can experience its own destruction as an aesthetic pleasure of the first order [?]." Mutatis mutandis, "this is the situation of politics which Fascism is rendering aesthetic. Communism responds by politicising art" (1986, 241).

In short, there is no "if" in, or calendar marking of, fascism's return. But if fascism permeates dimension of time and space ("history") as the heretofore theorists claim, it follows that political movement(s) do occur. Bodies intermingle, and they resist the pull toward authoritarianism. But there is more. If the desire for fascism presses on as a force from within "left" and "right," with "progress" the hollowing out of ideology the purported opposing forces seek to claim, what radical aesthetic possibilities exist? Until we come to terms with the bodily affect launched by the techno-aesthetic mechanisms currently at play in the twenty-first century work of art, we may be unable to disrupt the "storm we call progress". 


\section{References}

Adorno, Theodor W. 1997. Aesthetic Theory. Minneapolis, MS: University of Minnesota. Benjamin, Walter. 1986. Illuminations. New York: Schocken.

Foucault, Michel. 1991. Remarks on Marx: Conversations with Duccio Trombadori. New York: Semiotext(e).

Gerstner, David A. 1999. "Queer Angles of History Take It and Leave It from Behind." In Stanford Humanities Review: Inside the Film Archive: Practice, Theory, Canon (7:2): 150165.

Horkheimer, Max and Adorno, Theodor W. 2002. Dialectic of Enlightenment: Philosophical Fragments. Stanford, CA: Stanford University Press.

Internationale Situationiste. 1966. "On the Poverty of Student Life." Pamphlet published by students and faculty at the University of Strasbourg. Accessed January 20, 2017. http://library.nothingness.org/articles/SI/en/display printable/140

Michael Kinsley. 2017. "Donald Trump is Actually a Fascist." The Washington Post on December 9, 2016. Accessed January 20, 2017.

https://www.washingtonpost.com/opinions/donald-trump-is-actually-afascist/2016/12/09/e193a2b6-bd77-11e6-94ac3d324840106c story.html?utm term=.acc9a8ae59ff

Orwell, George. 2015 (1944). "What is Fascism?" In Tribune. Accessed January 20, 2017. http://www.orwell.ru/library/articles/As I Please/english/efasc

Weber, Samuel. 1996. Mass Mediauras: Form, Technics, Media. Stanford, CA: Stanford University Press.

Wheatcroft, George. 2015. "Whose Fascism Is This, Anyway?" The New York Times on December 15, 2015. Accessed January 20, 2017. https://www.nytimes.com/2015/12/16/opinion/whose-fascism-is-this-anyway.html

Wollen, Peter. 1993. "The Situationist International: On the Passage of a Few People through a Rather Brief Period of Time." In Raiding the Icebox: Reflections on TwentiethCentury Culture (120-57). Bloomington: University of Indiana Press.

\section{About the author}

David A. Gerstner

David A. Gerstner is Professor of Cinema Studies and Chair of the Department of Media Culture at the City University of New York's College of Staten Island. He also serves as a member of the doctoral faculty at the CUNY Graduate Center. His books include: Christophe Honoré: A Critical Introduction (with Julien Nahmias, Wayne State University Press, 2015); Queer Pollen: White Seduction, Black Male Homosexuality, and the Cinematic (2011, Choice Outstanding Academic Title, 2012); Manly Arts: Masculinity and Nation in Early American Cinema (2006); and The Routledge International Encyclopedia of Queer Culture (editor, 2006; New York Public Library "Best of Reference," 2007). His co-edited works include Media Authorship (with Cynthia Chris) and Authorship and Film (with Janet Staiger). His essays appear in numerous anthologies and journals. He is editor of the book series Queer Screens at Wayne State University Press, and completing a second volume that studies Honoré's cinematic mothers. 